Journal of Engineering Sciences, Assiut University, Vol. 37, No. 3, pp. 699-709, May 2009.

\title{
NUMERICAL MODELLING OF SURFACE SUBSIDENCE INDUCED BY UNDERGROUND PHOSPHATE MINES AT ABU-TATUR AREA
}

\author{
A. A. Elashiry (a) , W. A. Gomma ${ }^{(b)}$ and S. S. Imbaby ${ }^{(c)}$ \\ (a) Assistant Teacher in Mining \& metallurgical Engineering Department, \\ Faculty of Engineering, Assiut University, Assiut, Egypt \\ (b)\&(c) Professors in Mining\& metallurgical Engineering Department, \\ Faculty of Engineering, Assiut University, Assiut, Egypt
}

(Received March 4, 2009 Accepted April 18, 2009)

\begin{abstract}
Different methods have been adopted to predict and quantify the subsidence by the subsidence parameters. These methods can be classified into three categories as follows: - 1) Empirical methods based on the analysis of the field measurement, 2) Mathematical theories, 3) Numerical models including Finite Elements, Boundary Elements, and Distinct Elements methods. In this paper, the vertical component of subsidence is measured over working longwall panel at Abu-Tartur phosphate mines along transversal profiles at different face advancing rates. Finite element method (FEM) is applied to predict the subsidence trough over the excavated panel at different face advancing rates using three dimensional finite element program (Ansys package). The obtained results are compared with the measured ones. It was found that FEM results for surface subsidence coincide well with the measured data with a reasonable accuracy (correlation coefficient higher than 0.98). The degree of ground surface tilt, surface curvature and strain are obtained also by FEM model.
\end{abstract}

\section{INTRODUCTION}

Subsidence is the lowering of the ground surface due to underground excavation of an ore body when the stopped area is left unsupported. Subsidence is produced, to a greater or a less degree, by almost all types of underground mining methods. Surface displacement may result from the redistribution of stresses associated with an excavation forming a subsidence basin. The surface subsidence basin [Fig. 1] is elliptical in plan if the ore seam is horizontal or sub-horizontal, and the underground opening is rectangular in shape [1].

The ground subsidence process induced by underground long wall mining is a complicated process, as it deals with the process of subsidence-induced damage to the surface and sub-surface structures as building, pipelines, railways, neighboring underground workings, etc. [2,3]. The factors which affect the severity of mining induced structure damages due to subsidence over mines may be grouped into three categories, a) mining factors related to mining methods and dimensions of the excavation, e.g. panel dimensions, its depth below the surface, method of support, extracted height and the rate of face advance, b) site factors, which refer to the geotechnical conditions, such as type of strata, soil and rock properties, structural 
features, hydrology and previous workings, c) structure factors, such as size and shape of the structure, type of foundation and construction method, etc. [4,5].

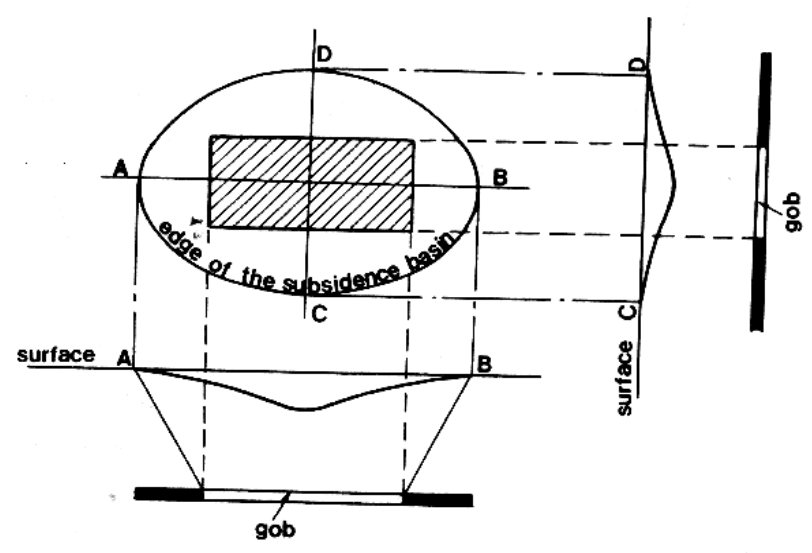

Fig. (1) Final subsidence basin.

The prediction of subsidence trough and determination of subsidence parameters such as tilt, curvature, strain etc. are very important for protecting surface structures against damages. Subsidence monitoring and prediction has a history of more than 100 years. Most of the early prediction theories were developed by mine surveyors. On the contrary, over the past twenty years, many mines have started recognizing new monitoring techniques to develop empirical methods and sophisticated numerical modelling of ground surface subsidence. It was found that these techniques were useful not only for legal liability and environmental control purposes but they may give also better understanding of the mechanism of rock strata deformation which leads to the development of safer and more economical methods [6].

Different methods for studying surface subsidence, reviewed by Brauner [7], are generally divided into three categories 1) Empirical methods, 2) Mathematical theory, and 3) Numerical models.

Empirical methods involve the following: a) analysis of data gathered from study of existing subsidence to enable predicting future subsidence effects. This method is a good choice to predict subsidence in the regions where initial data were taken, but their geographic extension is usually restricted [8]. The most popular empirical methods for predicting mining subsidence is the one developed by the National Coal Board [NCB] in England. NCB method has assumed that the subsidence profile is related to the width to depth ratio of the mined panel and to the seam thickness [9]. b) Physical models entail the construction of a scale model of the strata involved by a material, such as plaster. This expensive technique helped understand strata mechanics and subsidence mechanisms but it was not a good tool to predict displacement [8]. 
[Table 1] The properties of all rock types at Abu-Tartur plateau.

\begin{tabular}{|l|c|c|c|c|}
\hline & $\begin{array}{c}\text { Modulus of } \\
\text { elasticity, E. } \\
\left(\mathrm{GN} / \mathrm{m}^{2}\right)\end{array}$ & $\begin{array}{c}\text { Poisons } \\
\text { ratio, } v\end{array}$ & $\begin{array}{c}\text { Cohesion, C. } \\
\left(\mathrm{MN} / \mathrm{m}^{2}\right)\end{array}$ & $\begin{array}{c}\text { Angle of } \\
\text { internal } \\
\text { friction, } \Phi\end{array}$ \\
\hline Limestone & 14.4 & 0.3 & 17.5 & $33.5^{\circ}$ \\
\hline clayey-carbonate & 7.6 & 0.3 & 14.1 & $31.4^{\circ}$ \\
\hline $\begin{array}{l}\text { Phosphate- } \\
\text { argillaceous }\end{array}$ & 6 & 0.3 & 11.2 & $30^{\circ}$ \\
\hline Argillaceous sand & 6.7 & 0.3 & 6.3 & $35^{\circ}$ \\
\hline Papery clays & 7.2 & 0.3 & 6.6 & $34^{\circ}$ \\
\hline Phosphorite (the ore $)$ & 8.2 & 0.3 & 4.2 & $34^{\circ}$ \\
\hline variegated clay & 4.8 & 0.3 & 6.7 & $33.5^{\circ}$ \\
\hline
\end{tabular}

The mathematical approach to calculate movement in strata affected by underlying working can be kept at a justifiable level only if certain simplified assumptions are made. Thus in many procedures the rock mass is regarded as continuum, the separate constituents of which, are held together by cohesive forces [10]. Another definition is derived from mechanical relations between the loads (surface and body forces, initial stresses) and internal stresses. The mathematical models are more able to deal with a wide range of mining conditions than empirical models. Berry [11 and 12] analyzed the elastic ground movement for three conditions of underground excavations, a) nonclosure, (floor and roof never meet), b) partial closure and c) complete closure. The calculated displacements were smaller than those encountered in practice. Mathematical models have not achieved much success to this period (1960-1964), mainly due to the difficulty of representing complex geologic properties of the strata in simple mathematical terms. [13].

Numerical models have been made possible by advances in computer technology based on numerical approximations of the governing equations, i.e. the differential equations of equilibrium, the strain-displacement relationships, the stressstrain equations and the strength-stress relationships. They can simulate nonhomogeneous, non-linear material behavior and complicated mine geometries, including Finite element, Boundary element, and Distinct element methods are developed [14].

\section{SUBSIDENCE MONITORING AT ABU-TARTUR AREA}

Abu-Tartur phosphate mine is located at $150 \mathrm{~m}$ below the Abu-Tartur plateau, which is situated, in the southwestern sector of Egypt in the Western Desert $50 \mathrm{Km}$ west of El Kharga city, capital of the New Valley Governorate Egypt. The stratigraphic column along Abu-Tartur plateau and its rock properties are shown in Table (1) [15].

The phosphate deposit at Abu-Tartur area with average thickness $3 \mathrm{~m}$ is exploited by longwall mining method. Three panels, $1200 \mathrm{~m}$ long and $150 \mathrm{~m}$ wide, have been developed and only one panel is being mined now by retreat mining method with roof caving. The rate of face advance was about $0.63 \mathrm{~m} / \mathrm{day}$ (with irregular rate). The layout of the working panel is shown in [Fig. 2]. 


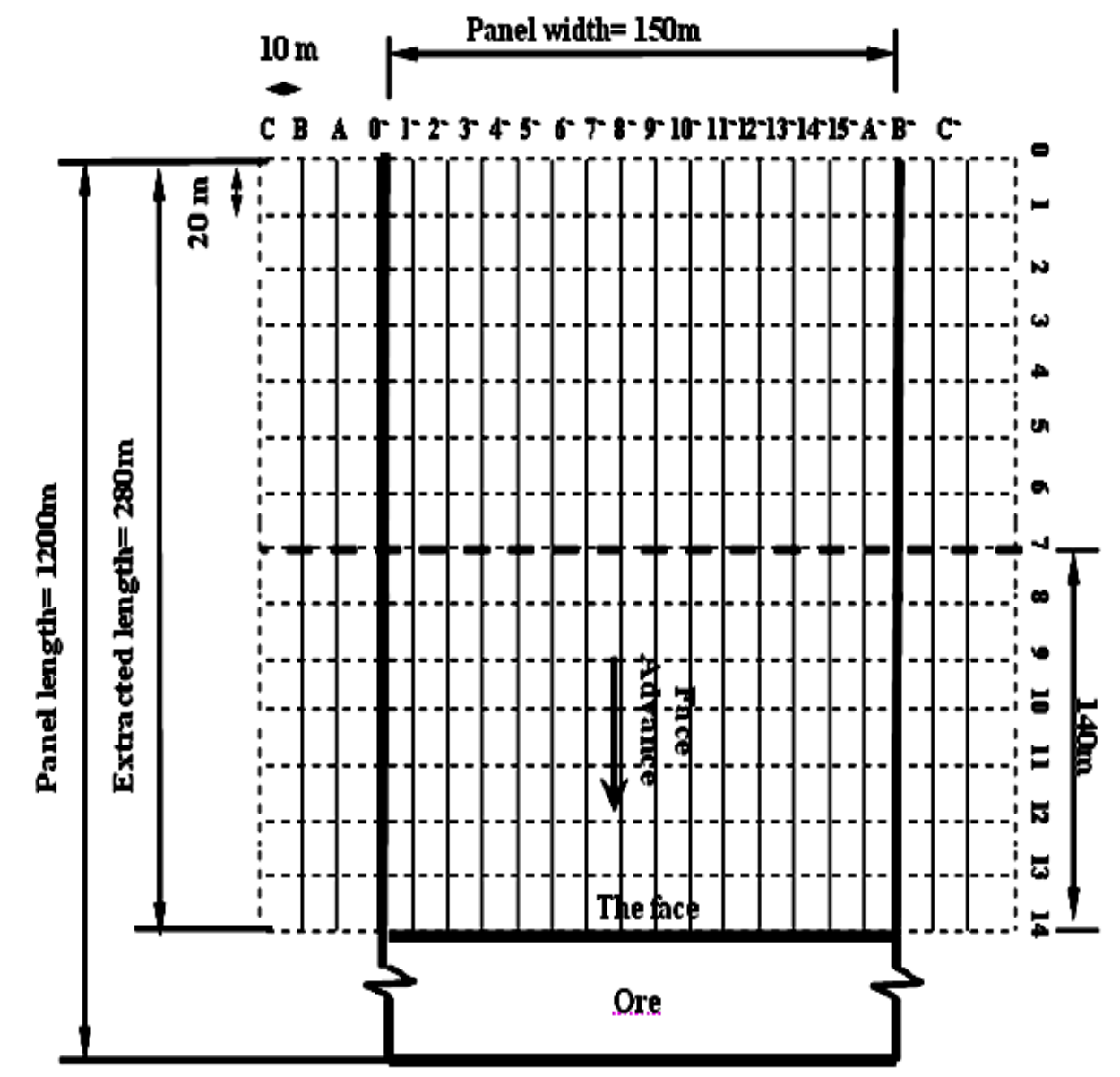

Fig. (2) Layout of working panel at Abu-Tartur phosphate mine and the grid of measurements.

Measuring of the vertical movement at all grid points using accurate surveying instruments were collected from June 2002 to June 2005 by Abu-Tartur phosphate Company. Rest of the data from June 2005 to April 2006 was measured by the authors. The dates and the face positions at all measuring times were recorded as shown in Table (2).

The vertical component of subsidence is measured along transversal profile 7 (As an example) at different face advancing. The measured values are plotted as shown in [Fig. 3].

From the final subsidence trough at transversal profile 7 [Fig. 4], the following parameters may be deduced:

1. The maximum subsidence $\left(\mathrm{S}_{\max }\right)$ from the measuring data is $2.67 \mathrm{~m}$, then the subsidence factor $(\eta)$ will be: $\eta=S_{\max } / \mathrm{h}=2.67 / 3=0.89$

2. The radius of major influences $(\mathrm{R})$ from measuring data is $75 \mathrm{~m}$, and then the angle of draw $(\beta)=\tan ^{-1}(\mathrm{R} / \mathrm{H})=27^{\circ}$ (Fig.3.9). 
[Table 2] The face position at all measuring times.

\begin{tabular}{|c|c|}
\hline Date of measuring & Position of face, $\mathbf{m}$ \\
\hline $29 / 05 / 2002$ & 28.2 \\
\hline $12 / 01 / 2003$ & 65 \\
\hline $20 / 05 / 2003$ & 94 \\
\hline $13 / 11 / 2003$ & 123.6 \\
\hline $22 / 05 / 2004$ & 152.8 \\
\hline $22 / 11 / 2004$ & 183.6 \\
\hline $18 / 05 / 2005$ & 214.3 \\
\hline $16 / 11 / 2005$ & 247.6 \\
\hline $06 / 04 / 2006$ & 283.2 \\
\hline
\end{tabular}

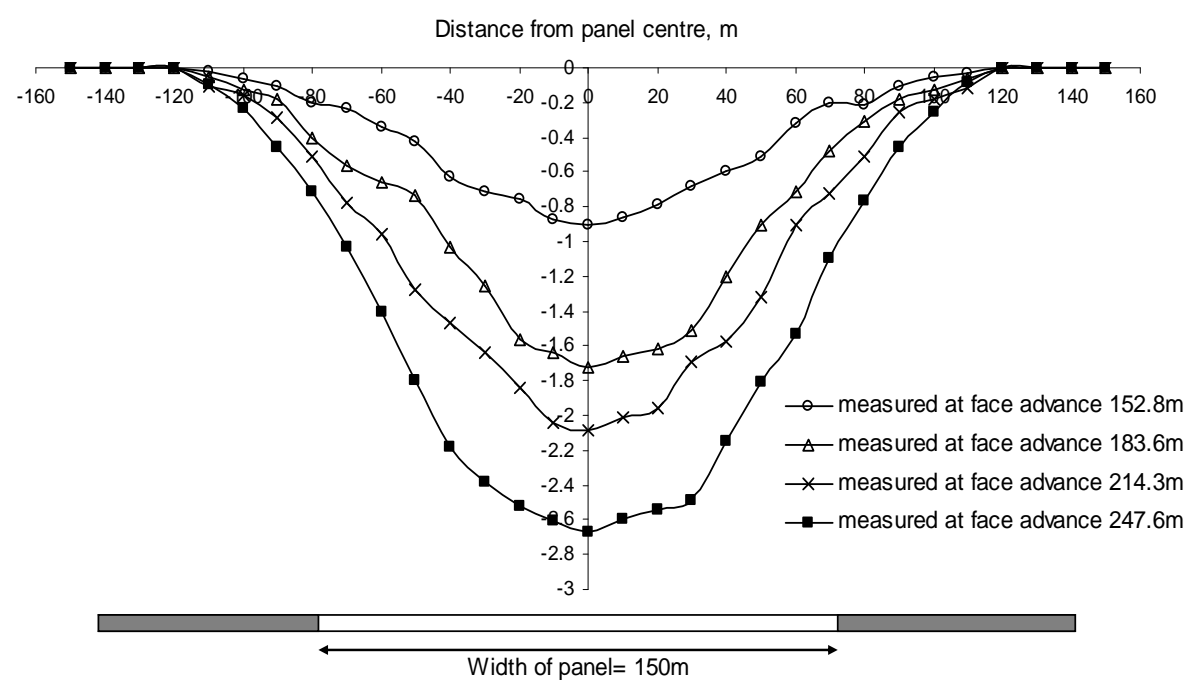

Fig. (3) The measured subsidence at transversal profile 7 over working panel at different face advancing

3. The distance of inflection point of the subsidence trough (i) at distance $60 \mathrm{~m}$ from panel centre because the value of subsidence at this point is equal approximately one-half of the maximum subsidence.

4. The mined area is in a critical situation because $\mathrm{W} / \mathrm{H}=2 \tan \beta$ then the case is critical.

\section{NUMERICAL PREDICTION METHOD (FINITE ELEMENT METHOD)}

The nonlinearity solution with three-dimensional finite element simulation for AbuTartur phosphate mine with the surrounding rock layers by Ansys program package is used to investigate the actual behavior of the surface subsidence at transversal profiles over Abu-Tartur mine for different rates of face advance. The modeling process of the studied mine has two main steps as follow: 


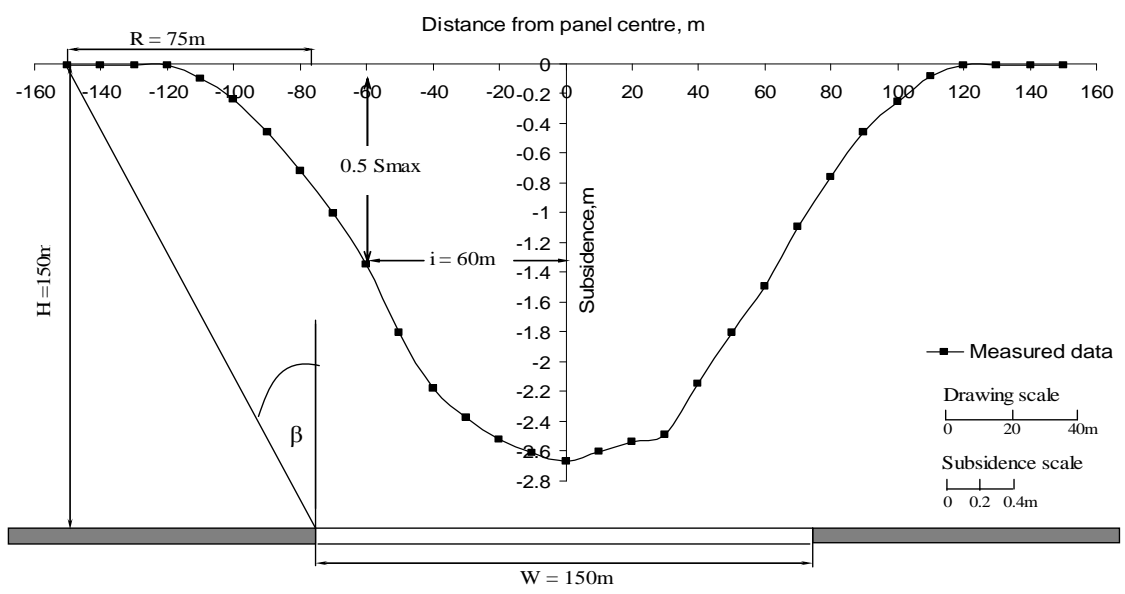

Fig. (4) The measured of final subsidence trough at transversal profile 7 over working panel.

\subsection{Pre-processor:}

\section{a) Model geometry :}

The steps of a true scale three dimensional modelling of phosphate longwall panel with ANSYS program package are given as follows:

1) Face width is $150 \mathrm{~m}$ at the panel, this value is taken on the $+\mathrm{Z}$ coordinate axis and the length of earth's section in this direction was taken in the model as $400 \mathrm{~m}$ to show the extension of subsidence trough at the surface.

2) The actual panel length is $1200 \mathrm{~m}$ due to the extracted length. This length changes in the model from 0 to $280.3 \mathrm{~m}$ (Table 3.2), the panel length is taken as $300 \mathrm{~m}$ on the $+X$ coordinate axis in the model.

3) The actual depth below the surface (overburden thickness) is $150 \mathrm{~m}$, this value is taken on the $+\mathrm{Y}$ coordinate axis in the model. This overburden consists of five layers over the phosphate mine with different thickness as shown in [Fig. 5].

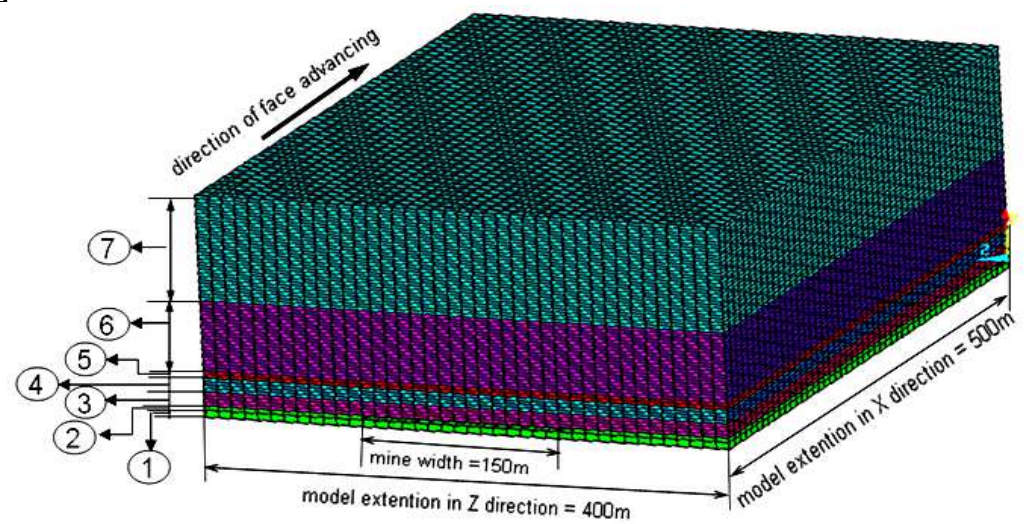

\footnotetext{
(1) Variegated clay with any thickness $5 \mathrm{~m}$ (2) Phosphate ore layer with thickness $3 \mathrm{~m}$

(3) Popery clays with thickness $10 \mathrm{~m}(2.5 \mathrm{~m} \times 4)$

(5) Phosphate-argillaceous with thickness $5 \mathrm{~m}(2.5 \mathrm{~m} \times 2)$

(6) Clayey-carbonate with thickness $50 \mathrm{~m}(2.5 \mathrm{~m} \times 20)$

(4) Argillaceous sand with thickness $10 \mathrm{~m}(2.5 \mathrm{~m} \times 4)$
}

Fig. (5) The geometry of the studied finite element model. 


\section{b) Elements type selection:}

Three different types of elements have been chosen for the studied model, namely are SOLID 45, CONTACT 174 and TARGET 170.

\section{c) Material model selection:}

The material model using for the studied model is Drucker-Prager model [elasticperfectly plastic] for any type of rocks [16]. The material properties for the rocks type used in the studied model are as shown in Table (1).

\section{d) Meshing:}

The studied model after meshing contains 371700 elements. The element dimensions are $10 \mathrm{~m}$ in Z-direction, $10 \mathrm{~m}$ in $\mathrm{X}$-direction and $2.5 \mathrm{~m}$ in Y-direction.

\subsection{Solution:}

\section{a) Boundary Conditions:}

The boundary conditions adopted for the finite element mesh are given as follows:

- The mine floor hasn't any movement so that the degree of freedom (DOF) in $\mathrm{X}, \mathrm{Y}$ and $\mathrm{Z}$ directions was restrained.

- The two sides of the model in X-direction were constrained in Z-direction.

- The two sides of the model in Z-direction and extraction face were constrained in X-direction.

b) Load type:

The applied load to the studied model is the dead load under gravity.

\section{RESULTS AND DISCUSSION}

The results of the finite element simulation (predicted subsidence) are presented and compared with the measured ones. Figures (6.a), (6.b), (6.c) and (6.d) show the measured and predicted subsidence values along transversal profile 7 for different rates of face advance.

From figures (6.a), (6.b), (6.c) and (6.d), it is found that the predicted surface subsidence values using finite element method have small differences compared with the measured data. In order to evaluate the validation of the predicted results from the numerical model, the values of the correlation coefficient (r) was calculated by (Equ. 1) [17] for all rates of face advance at transversal profile 7 and it is shown on each curve.

$$
r=\frac{n \sum x y-\sum x \sum y}{\sqrt{n \sum\left(x^{2}\right)-\sum(x)^{2}} \sqrt{n \sum\left(y^{2}\right)-\sum(y)^{2}}}
$$

The calculated results demonstrate that the range of correlation coefficients is (0.985-0.996) which is higher than 0.98.

\subsection{Determination of tilt, curvature and strain:}

The subsidence components as tilt, curvature and strain are obtained from ANSYS program at transversal profile 7 as an example (Fig.7) 


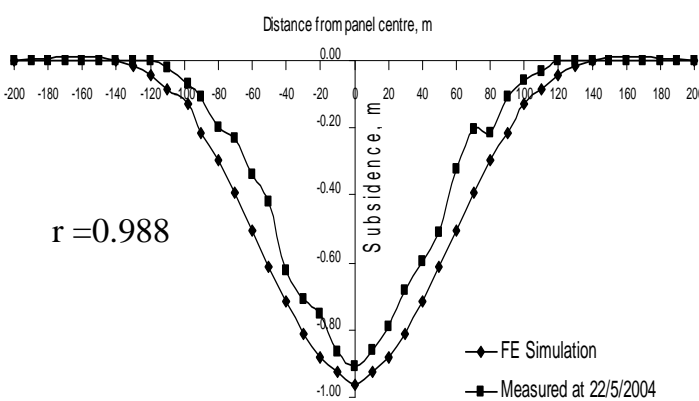

Fig.(6.a)Measured versus predicted subsidence values along transversal profile

7 after the face advanced $152.8 \mathrm{~m}$

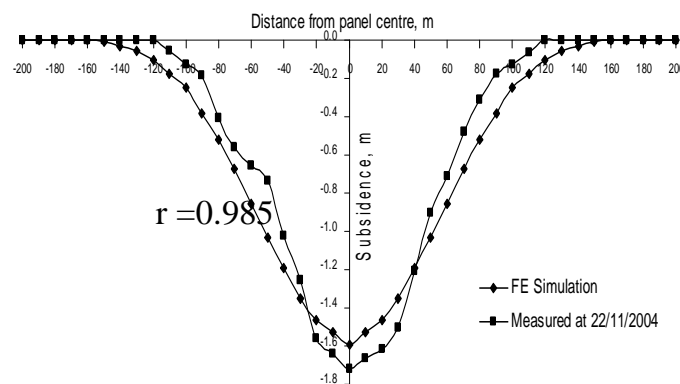

Fig.(6.b)Measured versus predicted subsidence values along transversal profile 7 after the face advanced $183.6 \mathrm{~m}$

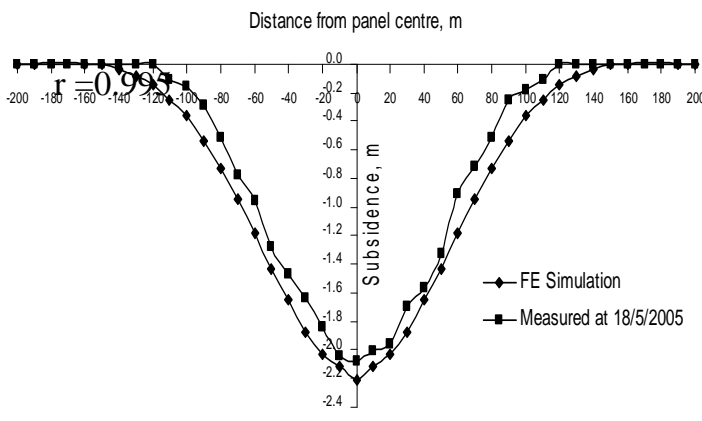

Fig.(6.c)Measured versus predicted subsidence values along transversal profile 7 after the face advanced $214.3 \mathrm{~m}$

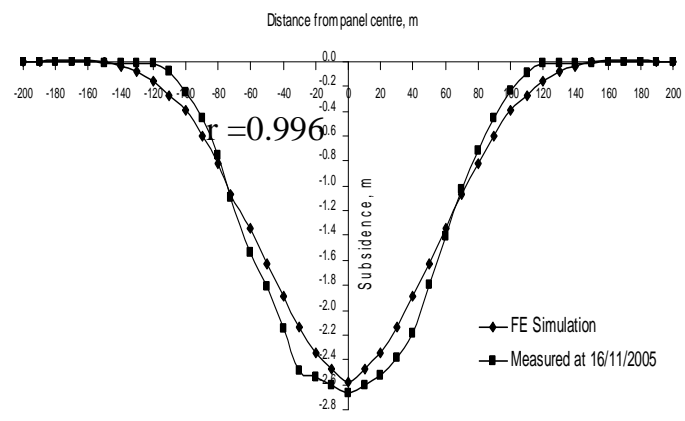

Fig.(6.d)Measured versus predicted subsidence values along transversal profile 7 after the face advanced $247.6 \mathrm{~m}$

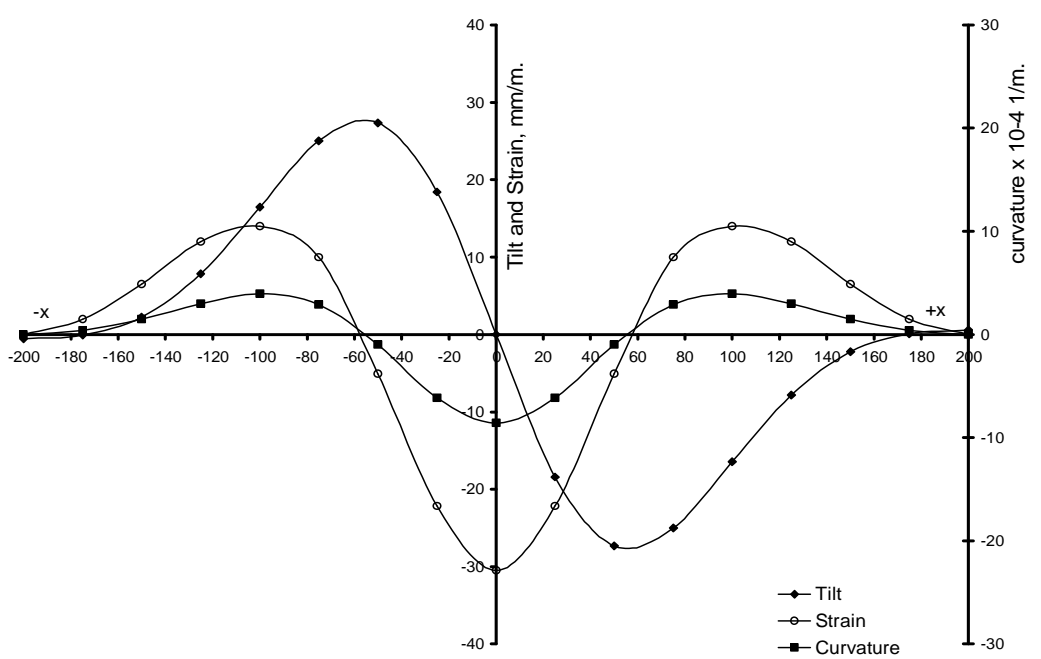

Fig.(7) Distribution of tilt, curvature, and strain from numerical model along transversal profile 7 
From figure (7) the point of maximum tilt on the ground lies above a point at a distance of $60 \mathrm{~m}$ approximately from the centre of panel (inflection point) and the value of tilt equals $-27.8 \mathrm{~mm} / \mathrm{m}$. The line of curvature has three peaks, the maximum one lies at the panel centre and equals to $-8.72 \times 10^{-4} 1 / \mathrm{m}$. Strain component has two types, compressive $(-\varepsilon)$ and tensile $(+\varepsilon)$. Compressive strain is noticed within the excavation limits with a maximum value of $-30.53 \mathrm{~mm} / \mathrm{m}$ at the panel centre and from transition point at distance $60 \mathrm{~m}$ from panel centre to the trough margin the tensile strain is noticed and has maximum value of $+14 \mathrm{~mm} / \mathrm{m}$ above a point at a distance of $100 \mathrm{~m}$ from the panel centre. The predicted values of tilt, curvature and strain are higher than that of the dangerous category [18], as shown in Table (3).

\begin{tabular}{|c|c|c|c|c|}
\hline $\begin{array}{c}\text { Damage } \\
\text { categories }\end{array}$ & $\begin{array}{c}\text { Horizontal strain } \\
(\mathbf{m m} / \mathbf{m})\end{array}$ & $\begin{array}{c}\text { Tilt } \\
(\mathbf{m m} / \mathbf{m})\end{array}$ & $\begin{array}{c}\text { Radius of } \\
\text { curvature } \\
(\mathbf{k m})\end{array}$ & $\begin{array}{c}\text { Curvature } \\
(\mathbf{1 0}\end{array}$ \\
\hline Very slight & $\varepsilon<0.5$ & $<2.5$ & $>50$ & $>0.2$ \\
\hline Slight & $0.5<\varepsilon<1$ & $<5$ & $>20$ & $>0.5$ \\
\hline Appreciable & $1<\varepsilon<2$ & $<10$ & $>11$ & $>0.91$ \\
\hline Severe & $2<\varepsilon<3$ & $<15$ & $>8$ & $>1.25$ \\
\hline Very severe & $\varepsilon>3$ & $>15$ & $<6$ & $<1.7$ \\
\hline
\end{tabular}

\section{CONCLUSIONS}

The movement over the working panel at Abu-Tartur area was predicted by applying finite element model. It was found that the obtained results from finite element model coincides well with the measured data with a reasonable accuracy (correlation coefficient higher than 0.98), i.e. the applied numerical prediction method of subsidence is valid and can be used in practice. As a result of that, the distributions of tilt, curvature and strain over the studied area are obtained from finite element model. By comparing the predicted values of tilt, curvature and strain with the values of Very severe categories, it was found that these values are dangerous. To minimize the dangerous effects, it is recommended to apply the method of ore extraction with filling or stowing in the rest of the working panel and in other unworked panels to reduce the probable strain values in Abu-Tartur area.

\section{REFERENCES}

[1] Peng, S.S. and Chiang, H., "Longwall Mining," John Wiley \& Sons, Inc. New York, 1984.

[2] Cui XM, Wang Jiachen, and Liu Yisheng, "Prediction of progressive surface subsidence above longwall coal mining using a time function". International journal of rock mechanics \&Mining science, August, 2001.

[3] Luo, Y. and Peng, S. S., "Subsidence Prediction Influence Assessment and Damage Control," 16th International Conference on Ground Control in Mining, Morgantown, WV: West Virginia University, pp. 50-57, 1997.

[4] Newman, D., Agioutantis, Z. and Karmis, M., "SDPS for windows: An Integrated Approach to Ground Deformation Prediction," Proceedings, $20^{\text {th }}$ 
International Conference on Ground Control in Mining, 2001, Morgantown, WV: West Virginia University.

[5] Gomma, W.A., Ibrahim, A.R, Imbaby, S.S. and Yousef, W.M., "Prediction of surface subsidence over longwall mining in Abu-Tartur area ", the fourth mining, petroleum\& metal conf. faculty of engineering, Assiut univ., assuit, Egypt, 1994.

[6] Chrzanowski, A.S., and Forrester, D. J., "100 years of ground subsidence studies" proceedings (CDROM) of the 100th CIM Annual General Meeting Montreal, Canada, May, 1998.

[7] Brauner, G. "Subsidence due to underground mining. I. Theory and practices in predicting surface deformation," (in two parts), 1973, USDI Bur. of Mines. IC8571

[8] Alejano, L.R., Ramirez-Oyanguren, P., and Taboada, J.,"FDM predictive methodology for subsidence due to flat and inclined coal seam mining". International journal of rock mechanics \&Mining science, February, 1999.

[9] National Coal Board. "Subsidence Engineering Handbooks", London 1st edition. 1966.

[10] Kratzsch, Helmut, "Mining Subsidence Engineering," Springer-Verlag, Berlin, 1983.

[11] Berry, D. S., and T. W. Sales, "An Elastic Treatment of Ground Movement Due to Mining ", J. Mech. Phys. Solids, Pt. 1, Vol. 8, pp. 280-292, 1960.

[12] Berry, D. S, "A Theoretical Elastic Model of The Complete Region Affected by Mining a Thin Seam", Proc. 6th Symp. Rock Mech., Rolla, pp. 310-329, 1964.

[13] Blodgett, S. and Kuipers, J. R., "Underground Hard-Rock Mining: Subsidence and Hydrologic Environmental Impacts". Center for Science in Public Participation, Bozeman, MT, 2002.

[14] Eesnay, M. "Development of a Subsidence Model for ÇAYIRHAN Coal Mine", Ms.c., Turkey, 2004.

[15] Ibrahim, A.R., and Imbaby, S.S., "Rational Support Parameters At Mines (AbuTatur Mining Conditins)", Al-Azhar engineering second international conference, 1991.

[16] Help of "ANSYS Program Package", version 10

[17] Fogiel, M., "the statistics problem solver". Research and education association, New Jersey, 1978.

[18] Al-Heib M., Nicolas M, Noirel J.F and Wojtkowiak F., "Risidual Subsidence Analyses After the End of Coal Mine. Work Example from LORRAINE Colliery, FRANCE,” Post-Mining, November 16-17, Nancy, France, 2005. 
النمذجه الرياضية للهبوط السطحى الناتج من مناجم الفوسفات بمنطقة ابوطرطور

(3)

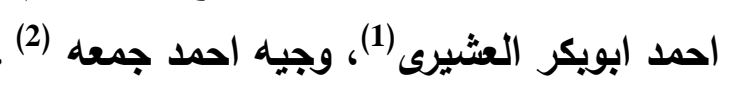

(1) مدرس مساعد بقسم التعدين والفلزات، كلية الهندسه، جامعة اسيوط، مصر .

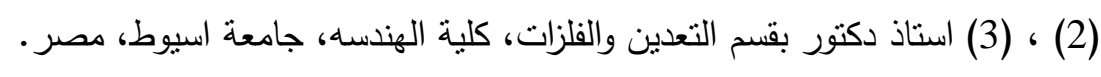

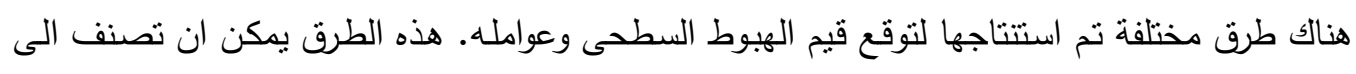
ثلاثة انواع وهى: 1) الطرق التجريبيه التى تستتد على تحليل القياسات الحقلية، 2)النظريات الرياضية،

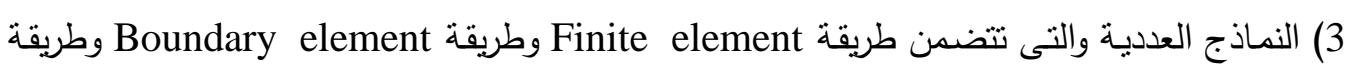
Distinct element طريقة الحائظ الطويل لإستخراج الفوسفات فى منطقة ابوطرطور وذلك عند معدلات مختلفة لتقدم واجهة الحش. وقد تم تطبيق طريقة Finite element بعدل نوذج ثلاثى الابعاد وذلك بأستخدام برنامج ANSYS

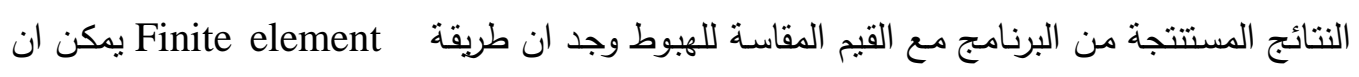

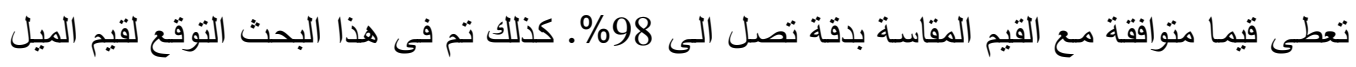

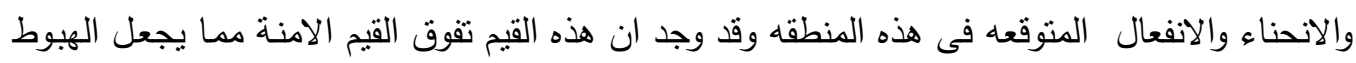
فى هذه المنطقة يدخل فى منطقة الخطر . 